\title{
Mak Wok, Spice Mistress
}

\section{P. Lim Pui Huen}

Mak Wok was mistress of spices in the Istana kitchen. She was in charge of preparing the rempah, the grounded spice combinations needed for cooking the various dishes. She also made the sambal, the fiery sauces and dips that were either eaten with ulam, the traditional Malay salad, or as a side dish with meat or fish, because a dash of sambal added a sharp and piquant flavour to the meal. The kitchen used a large variety of fresh herbs that were grown in the royal gardens - several kinds of chillies, gingers, limes, and onions as well as plants cultivated for their leaves and flowers or for their roots.

She squatted on the floor in front of the batu giling with her ingredients and favourite cooking pots arranged on the floor around the slab of grinding stone. She placed some garlic, onions, turmeric, candlenuts and chillies on the stone slab and taking the rolling stone, smashed the ingredients and deftly ground them into a smooth paste that she scooped into the pots with her fingers.

Because the royal kitchen served the royal family and members of the court, it was amply provided with all kinds of serving and cooking utensils. For serving food, there were large brass trays and lots of blue and white porcelain plates from China, while drinks were served in clay water bottles or in kendi with long slender spouts. Then there were brass pots and kettles from Brunei, earthenware water jars from Siam, and cooking pots of all shapes and sizes. But her favourites were a set of three small brass pots that fitted into one another. They were just the right size for sambal and rempah and she often looked at them with longing. They were a convenient size for family cooking and so much nicer than the clay pots she used at home.

Every morning, she would ask Pak Sabu what dishes he planned to cook and prepare the necessary spice combinations. He was the head of the kitchen and lord of every object and every person inside. He was a short man who despite his considerable paunch, managed to move quickly and nimbly between the different sections of the kitchen. There was no doubt that he was a good cook, equally expert at roasting a whole deer or small sticks of satay.

Of course, Pak Sabu sometimes changed his mind about the menu, or rather, their royal masters and mistresses changed their minds - well, that was the privilege of the Exalted Ones. While they were discussing the dishes for the day, he patted her bum and gave it a squeeze. Mak Wok never quite knew how to respond. If she showed she liked it, she would get more and that was the last thing she wanted. If she showed she did 
not like it, she could offend him and that could be a problem too. Most of the time, she just ignored it so that at least he would not know how she felt. That was her only defence.

Only last week, she had forced herself to smile at him and said, "There is a lot for me to do nowadays. Can I bring my daughter to help me?" He had grunted which she took to mean a kind of ambiguous yes. That was how Sapiah started working in the royal kitchen two days ago and Mak Wok could keep her daughter under her eye. She was growing up and growing up too fast. Her breasts were beginning to show and men were beginning to look at her in a way that Mak Wok did not like at all.

Suddenly, the war drum on the watchtower sounded. The watchtower stood at the highest point in the middle of the bastion that jutted out from the stockade of Kota Batu, the fort that defended the entrance to the Johor River. It was being beaten very hard, very rapidly and very urgently.

Boom boom! Boom boom!

Boom ka-boom! Boom ka-booom!

Everyone in the kitchen stopped to listen. They understood the message.

"To your stations! Enemy ships sighted!"

They looked at each other. What should they do? What could they do? They were only cooks. They were not the fighting men.

The Istana was built on the slope of the hill and the building was raised on stilts with the entrance facing the main street. The kitchen was located in a separate building behind the Istana so that the noise and odours from food preparation would not disturb the elegant inhabitants of the palace. They rushed outside to look through the stilts to see what was going on in the main street. Men were rushing to their battle positions with their spears and weapons.

Then the guns started booming. The firing of cannons from the stockade sounded very loud in their ears and the response from the attackers' guns sounded further away. But the attackers seemed to be moving close very fast. They also seemed to have more guns and a barrage of heavy fire fell all around them. The booming of guns now seemed to come from all sides and everywhere.

\section{Boom boom ka-booom!}

The ground shook and shuddered. Through the thunder of the guns, they heard the crash of falling timber and the screams of people injured or trapped underneath. People screamed and shouted in panic and ran all over the place in confusion.

A young man rushed in shouting, "Pak! Pak!"

Mak Wok recognised him as one of Pak Sabu's sons.

"Pak, you must leave. At once! The enemy is too many for us. Too many warships."

"Who are they?" 
"Jambi!"

A cold fear closed round their hearts. Johor had many enemies, Jambi on the coast of Sumatra was the deadliest and most ferocious.

They heard the rustle of many running feet clad in silken slippers. They saw flashes of silk and colour that rushed out of the palace down the main street. They also heard the cries of mindless fear.

The palace people are leaving!

The Exalted Ones are leaving!

And their guards too!

What about their fighting men?

Where are their fighting men?

"Run! There is no time to lose!"

"Run! Run for your life!"

"Sapiah!"

Mak Wok's thoughts flew straight to her daughter - except that Sapiah was nowhere to be seen. Where was that girl? Then she remembered. The building next door was the kitchen that cooked for the guards and servants. She had sent Sapiah next door to get some kafir limes.

She picked up her small knife, tucked it into her head cloth and ran screaming into the other kitchen, "Sapiah! Where are you?"

As she ran out of the kitchen, the rafters swayed and the oil lamps overhead swung and crashed to the floor. Timber fell on the stoves and caught fire. The sound of the war drum that had been beaten so frantically had tapered off. Had their men been overcome?

Mak Wok pushed her way through the dazed and milling crowd to the other kitchen and ran inside still screaming, "Sapiah! Sapiah! Sapiah!"

She found her daughter huddled in a corner crying and paralysed by fear. She pulled her up by her arms, "Come, let's go."

Then she remembered the pots. She had been working near the doorway. They must still be there on the floor next to the batu giling. The royal kitchen was burning now but the doorway was still standing. She pulled Safiah along and darted in through the door, emptied the contents of the pots on to the floor, piled them together in her arms and was about to run off when she heard a soft cry.

"Kak Wok, Kak Wok, tolong."

She peered through the dust and smoke and saw Mak Som lying on the floor. Some pieces of wood had fallen on her and she was desperately trying to crawl out from under the smoking timbers.

“Tolonglah, Kak! Tolong!" 
Mak Wok dragged the timbers away while Sapiah helped Mak Som to get up. Together with the old lady in the middle, the three women made their way through the fallen debris and burning timbers to the main street.

People were still running down the street but the Jambi men had already landed and were fighting their way from the beach up the main street towards the palace. They could not go that way. They looked up towards the bastion on the hill. Their own men could not be seen and Jambi men were coming through gaps in the wooden palisades. They were trapped in between.

While they were deciding which way to go, a bearded warrior with a cloth tied round his long hair ran past and stopped in front of them. He was obviously young as his beard was still tender. They stared at him in shock as he raised his bloodied kris. Somehow, Mak Wok managed to quaver, "We are old women. Do you have a mother?"

He glared at her with hate in his eyes and made threatening motions with his kris. Then he spat at her, kicked some earth at her face and ran off.

Cradling her precious pots in her left arm and holding up Mak Som up with her right hand, Mak Wok pulled them across the main street. "This way," she shouted as she ran. Then she tripped and stumbled. The pots fell with a clang and rolled down the slope. She scrambled up and ran after the pots.

“Janganlah, Mak, jangan!” cried Sapiah,

"Baleklah, Wok, balek," implored Mak Som.

Mak Wok ran towards the pots and fell again. This time, Sapiah and Mak Som grabbed her and together dragged her into a shed on the opposite side of the main street. They peered out from a small window. There were still men on the main street but the sound of battle had moved beyond the palace area and was raging in town further down the hill. This side of the main street where they were hiding, was lined with the shacks where the guards and fighting men slept and took shelter from the rain. Fruit trees and bushes grew between these sheds and the wall of the fort. The women pulled their sarongs over their heads, rolled themselves up into a ball and huddled in the darkest corner of the shed. They heard the voices of men in the distance but not the sound of fighting. The battle was over. They feared the worst.

When darkness was falling, Mak Wok got up and peered out of the window of the shack. She had hoped they could make their way to the kitchen to get some food. Then she saw men in the shadows. They were going into the smoking ruins of the Istana and the Balai and were carrying armfuls of stuff out of the ruins. She suddenly realised, the palace and the royal kitchen were full of desirable things.

"We go this way," she said, and sheltered by trees and bushes, she led them to the wall of the stockade. The earthworks stood high above their heads and the wooden palisade on top of the earthen walls stood higher still. They followed the wall of the fort all the way until they came to the royal gardens and went to the far 
end to the shack where the gardeners kept their baskets and tools. The three women gathered fallen branches and pulled up bushes, and piled them like a wall round the shed behind which they could hide. Now that they found a safe haven, they felt hungry for they had not eaten lunch. Mak Wok looked around the banana trees and found a bunch of ripening bananas. It felt unreal, sitting in a quiet corner of the garden eating bananas when their town had been destroyed and their friends killed.

Mak Wok looked at Sapiah. She was becoming really pretty and would be a beautiful woman when she grew up. But now, at this moment, it was dangerous to be a pretty girl.

"Sapiah," she said, "come over here and sit down in front of Mak."

The girl obeyed. He mother took her knife, grabbed bunches of her hair and began cutting it roughly.

"No, Mak, please don't," she wailed and struggled.

Mak Wok gave her a sharp slap. "Stop it and stop making noise. Do you know why I am doing this?"

The girl shook her head. Mak Wok said gently, "In times like this, men do bad things to girls, do you understand?" Sapiah nodded.

"I want you to look like a boy. I want you to behave like a boy."

"I'll try, Mak," she sobbed. Her mother rubbed her hand on some earth and smeared the dirt all over her face.

"Now, stand up. I want you to pull your sarong through your legs and tuck it in front the way men do when they are working. Can you do that?"

She nodded and her mother rubbed dirt over her arms and legs as well. Then she hugged her daughter and whispered, "Mak will look after you and make sure no harm will come to you."

They picked various leaves and fern shoots for ulam which they laced with the juice of green limes and bird's eye chillies. Eaten on a banana leaf together with what remained of their bananas, dinner was not too bad.

They spent the night in the garden shed rolled up in their sarongs again. When they woke up, they each cut a large banana leaf and hiding behind it like a shield, crept quietly through the trees and bushes until they reached a place where they could see the beach below. They saw some enemy ships on the shoreline and men sitting on the beach. They heard the men speak in Malay but with an unfamiliar accent. They were obviously waiting for something. How long would they stay? There was food in this garden. They might come and look for food here. There was no time to lose. Mak Wok motioned to Mak Som and Sapiah.

"Quick, as quickly as you can."

They pulled down the fruits from the papaya trees and threw them into the bushes. There were some jackfruit and champedak that were not yet ripe but they cut them down all the same. Fortunately, the rambutan and mangosteen trees were not in season. While Mak Som and Sapiah picked chillies and limes and whatever 
edible food they could find, Mak Wok cut down bunches of bananas that were beginning to ripen and dragged them to their shack. They had food, there was a small stream running behind the shack. They could live through this.

Later that morning, they heard men talking in the garden. "There is nothing here," one voice said and they heard the Jambi men walk away. They dared not leave their hiding place after that except to creep to their lookout place to see what was going on. They saw a lot of men who poked about the ruins of the buildings but most of the time, the men just sat and waited.

Their heart sank when they saw ships returning from upstream and feared for the fate of their own people. When all the ships were anchored on the beach, they were as thick and as close together as the fronds of a coconut palm.

The returning ships must have been what the Jambi commanders were waiting for. The ships were gone by afternoon.

But still they waited.

Only when they felt sure that the ships would not return and not one man had been left behind, did they emerge from their hiding place. Kota Batu had been completely gutted. The Istana, the Balai, mosque, the watch tower, the houses - everything had been burnt to the ground. They took a slow and sorrowful walk round and looked at what used to be their homes and at the bodies of people who used to be their neighbours. Other people began to emerge out of the trees, walking back from their hiding places in the jungle.

Mak Wok looked at the dejected people around her and said with a confidence that she did not feel, "We have survived. We shall rebuild our homes. We shall live again."

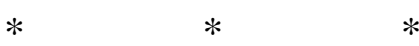

Kota Batu, now known as Johor Lama, was sacked many times, the last time in 1673 by a large force from Jambi. It was never rebuilt.

Some years ago, an archaeologist visited Johor Lama and saw three dark circles on the path. As perfect circles do not occur in nature she was convinced these were the rims of three pots buried in the ground.

She dug into the earth with a pen knife and excavated three small pots, a task that had to be done with great care as the metal had deteriorated to the constituency of cardboard. She took the three balls of earth to the Ketua Kampong and instructed him to send them to the National Museum. When she told me how she found the three pots, I was inspired to write this story of women in war. 